\title{
НИКИФОР КРИНИЦЬКИЙ, ЧИ ЕПІФАНІЙ ДРОВНЯК - ФЕНОМЕН ОСОБИСТОСТИ
}

\author{
Uljana Cholodová \\ Univerzita Palackého v Olomouci \\ Ołomuniec, Czechy \\ ORCID: 0000-0002-1950-2225
}

\section{NIKIFOR KRYNICKI OR EPIFANIY DROVNIAK - PERSONALITY PHENOMENON}

\begin{abstract}
The article is dedicated to the phenomenal artist Nikifor Krynytskyi, a representative of the naive art from the Polish town of Krynica-Zdrój. His paintings were globally acknowledged and recognized, but the self-taught painter was not aware of this until the end of his life. Being deaf-mute since birth and almost illiterate, he conveyed his attitude to the world around him with his unsurpassed paintings. The article deals with the issues of his life and artistic journey as well as the question of the artist's real name and his nationality.
\end{abstract}

Key words: phenomenon, self-taught painter, naive painting, nationality.

Серед численних скарбів українсько-польського культурного надбаннявагоме місце посідає геніальний митець-самоук, із дитинства фізично кволий, напівбожевільний,із вадами мовлення, який своїми неперевершеними картинами сягнув високої межі світової слави.

Позашлюбний син бідної глухонімої покоївки у готелях виростав у прекрасному старовинному польському курортному містечку Криниця, оточеномузвідусіль горами Бескидами. Як відомо, у Криниці та прилеглих гірських місцинах із давніх-давен проживали лемки, яких було звідти депортовано під час акції “Вісла" у 1947році'.Лиха доля переселення зачепила i самобутнього художника, картинами якого вже почав цікавитися мистецький світ, зокрема після славетної виставки двохсот його малярських робіт у Парижі (1932р.) у галереї Леона Марселязав-

Див. С. Рябенко, Операція “Вісла”: геноцид, воєнний злочин чи етнічна чистка, Історична правда 2020, [мережа Інтернет:] https://www.istpravda.com.ua/articles/2020/ 07/10/157801/, доступ: (15.04.2020). 
дяки старанням львівського художника Романа Турина. Декілька разів його намагалися вислати з Криниці з різних причин, найперше звинуватившиу співпраці з УПА, начебто у створенні мапи свого містечка. Проте, долаючи величезні відстані, всесвітньо відомий криничанин знову і знову повертався до автентичного місця, до рідного містечка². Саме через побоювання бути вивезеним або ув'язненимвідомий польський художник не хотів зізнаватися лемком Епіфанієм Дровняком, але відповідав на ім'я та прізвище НикифорКриницький, яке йому було вписано до офіційно наданого польського паспорта. Без документів не можна було подорожувати до різних міст і за кордон, де дедалі більше виставлялися його картини.Змалку малописьменний, але 3 величезною здібністю зображати навколишній світ під грифом власної майстерності, завжди прагнув стати справжнім митцем. Він старанно підписував свої твори, хоч досить часто з орфографічними помилками та змішаними кириличною та латинськоюабетками, найчастіше як Никифор з Криниці, Матейко з Криниці, Ян Матейко та ще загалом до сімнадцяти варіантів ${ }^{3}$. Найбільшим задоволенням і радістю для неповторного майстра наївного малярства із завойованою популярністю і подивуванням серед найвимогливіших поціновувачів світового художнього мистецтва було зайняти звичне місце біля тротуару у людному місці рідного курортного містечка iз табличкою "Просив би шановне панство про допомогу й підтримку для бідного каліки, хто чим може!"4. I вкинуті копійки за картини втішали його значно більше, ніж великі гонорари від успішних виставок у славнозвісних галереяхІталії, Франції,Бельгії, Великобританії, Швейцарії, США, Бразилії, Ізраїлі, Югославії, Чехословаччинита багатьох інших. Таким вуличним художником він залишився впродовж усього свого життя до трагічного моменту загострення хронічного туберкульозу, коли 10 жовтня 1968 р. його праведна душа полинула у кращий справедливіший світ, у який жертовний художник свято вірив і намагався передати нам це своїми наївними картинами. У тому “вищому світі” вже не діють земні закони, жодного значення немає ані маєтність, ані національність, ані політична приналежність. Тому в одній із картин бачимо зображених поруч за одним столом із келишками горілки антагоністичних лідерів Пілсудського та Сталіна 5 . На небі вони вже колеги, бо там усі рівні йуже немає сенсу для протистояння.

\footnotetext{
2 O. Noha, NikiforEpifaniiDrowniak: Ukrainischer Maler aus dem Lemkenland, ред. M. Markowicz, Düren 2005, s. 91.

Р. Коломієць, Никифор Дровняк, Харків 2020, с. 3.

4 Я. Бутенко, Матейко з Криниці, “День” 2021, мережа Інтернет: https://ay.kyiv.ua/uk/ article/kultura/mateyko-z-krynyci, доступ: (14.03.2020).

Oles Noha, Michael Markowicz, NikiforEpifaniiDrowniak: Ukrainischer Maler aus dem Lemkenland(Ukrainian Art History), Jan 1, 2005. цит. праця, s. 105.
} 
Малярська майстерність Никифора приваблює саме тим, що вона абсолютно оригінальна і самобутня. Никифор ніколи не вчився малювати у художній школі. Він був митець-самоук із власним способом творчості. Він не зазнав впливу відомих і визнаних мистецьких течій.Своє уявлення про світ він здебільшого черпав зі святих образів греко-католицької церкви в Криниці. Це і була для нього школа малювання. Никифор у своїх картинах створював те, чого йому не вистачало в реальному житті. Мистецтво стало для нього своєрідним способом вияву фантазії як утечі від дійсності. І тут уже між цими поняттями стиралася межа ${ }^{6}$.

До дійсності, яку Никифор віддзеркалював власним мистецьким способом, додавалася наївна й абстрактна інтерпретація побаченого. Він по-особливому сприймав світ і по-художньому, з великим хистом майстра, відображав його. Його світогляд значно відрізнявся від звичного світогляду пересічних людей, які певним чином звикли і навчилися сприймати та інтерпретувати реальність цього світу. Отже, саме цим його сприйняття було несподіваним і бентежним. Никифор показав нам у творах свій внутрішній наївний і сюрреальний світ, у якому немає нічого однозначного.

А дійсність насправді була жорстокою для ЕпіфаніяДровнякавже із самого дитинства. Відомий у народі як Никифор, народився, ймовірно, 21 травня 1895 р. у польському місті Криниця, яке було знамените своїми лікувальними водами. Його мати Євдокія була бідною неписьменною жінкою, яка виконувала допоміжні роботи на місцевих курортах.Від своєї матері Никифор успадкував ваду слуху та мовиㄱ․ Існують припущення, що батьком Никифора був один із відпочивальників - відомий художник Герасимський, бо важко було зрозуміти,звідки ж у такого замкнутого і майже глухонімого хлопчика такий неперевершений талант. Звісно, що мати, яка виховувала його самотужки, часто мусила залишала сина прив'язаного у люльці, зокрема під мостом, та йшла працювати, щоб хоч якісь “копійки” заробити на прожиття своє та сина. Бувало і так, що майбутній художник світового рівня поневірявся по чужих руках, особливо коли його мати померла, зазнав безліч знущань та насмішок спочатку від дітей-ровесників, а далі, у дорослому віці, від різних людей. Вони не сприймали його як художника, адже він умочував пензлика у власну слину та потім у фарбу і так малював. А коли дізналися про туберкульоз митця, то почали всі картини спалювати в печах. Пізніше, дізнавшись про шедевральність його робіт, часто викрадали або виманювали їх за копійки. Могли знущатися і таким чином, що викрадали і гроші або інші

Oles Noha, Michael Markowicz, NikiforEpifaniiDrowniak: Ukrainischer Maler aus dem Lemkenland(Ukrainian Art History), Jan 1, 2005. цит. праця, s. 39.

7 A. Banach, Nikifor, Warszawa 2004, s. 162. 
цінні речі, які художних отримував у подарунок від поважних відомих людей, поціновувачів його неземного хисту 8

Проте Никифор перебував у “своєму світі”, знав “свою правду” і не тримав образ ні на кого, також нічого не вимагав. Він жив занурений у мрії та фантазії, відображав навколишній світ крізь призму власного світогляду. Никифор вирішив для себе, що його послання - бути художником, і він був ним безперервно, усіма часточками душі й тіла. Відомий поет, есеїст і публіцист Вадим Лесич зазначав: „Малярська творчість для нього - все. У ній замикається його ставлення до світу та до людей, до того, що існує, і до того, в існування чого незламно вірить. Малювання

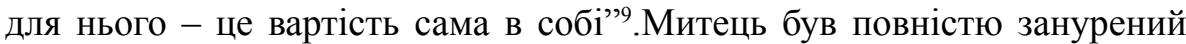
у малювання. На прожиття йому вистачало дуже мало - шматок хліба і вода, завжди спав на підлозі й не визнавав ліжка, жодного комфорту. Він ніколи не жебракував, а просив допомоги в обмін на свої картини та завжди ними розплачувався, ставлячи свій підпис або печатку "Матейко з Криниці". У своїх картинах він часто зображав себеу ролі вчителя, урядовця, настоятеля церкви чи святого. Никифор у своїх картинах був завжди елегантно вдягнений, часто мав над собою парасольку. Згідно 3 думкою югославського дослідника Ото Бігалі-Меріна, цим "наївного типу маляр компенсує свою неграмотність, на землі - приписуючи собі роль мудреця, а в небі - змальовуючи себе у колі святих"10.

Досі невідомо, чи маляр навчився писати та читати, чи він просто перемальовував різні надписи для своїх картин. Його пробували віддати до школи, проте шкільне навчання йому давалося важко, а тому його довелося покинути. Зате бажання та хист малювати були у Никифора 3 раннього дитинства. Спочатку він робив спроби малювати грифелем на дошці, а згодом і олівцем на клаптиках паперу. Пізніше почав використовувати для малюнків акварельні фарби, змішував темперу й олійні фарби і також під кінець життя використовував олівці. Перший свій пензель він виготовив зі щітки для гоління, коли працював прибиральником у перукарні. Для малюнків Никифор використовував усе, що для цього годилося, і малював з обох боків, аби заощадити папір.Це був пакувальний папір, обкладинки зошитів, обгортки від шоколаду, старі урядові акти та ін. Сюжети його творів були тісно пов'язані з вірою матері й давніми лемківськими церквами. Він по-своєму бачив святих і таким чином зображав їх у своїх картинах. Серед них, скажімо, такі як Святий Мико-

\footnotetext{
8 Н. Кляшторна, Хотів лемко малювати, Україна молода, 2003, 9 липня, цит. за:Fundacja „LosyNiezapomniane”, [мережа Інтернет:]http://www.los.org.pl/index.php?glowna=publicys tykaszczegoly\&idealny=36 доступ: (19.05.2020).

В. Лесич, Никифор з Криниці, Мюнхен 1971, с. 26.

10 O. Bihalji-Merin, Modern Primitives: Masters of Naive Painting, New York 1961, s. 143.
} 
лай, Таємна вечеря, Святі в літаку, Христос навчає, Христос благословляє та ін. Далі до сюжетів його творів належали автопортрети, побутові сценки 3 життя міста, навколишні краєвиди. Особливо вражають яскраві барви малюнків, зображення “квітучих" міст із вікна потягу, висотних будинків, мегаполісів, часто - з висоти пташиного польоту. При цьому Никифор майже не подорожував і не літав аеропланами. Це все були нездійсненні мрії, оригінальне бачення краси життя духовно вільної людини, надмірно необтяженої земними турботами, передані нам мовою мистецтва ${ }^{11}$.

Проте мрії не були марними, і доля змилостивилася над художником-самоуком. Першовідкривачем його таланту вважається львівський художник Роман Турин. За його сприяння картини Никифора потрапили на виставку в Париж (1932p.). Пізніше, у 1938 році, польський художник Сжи Вольф опублікував нарис Малярі наївного реалізму в Польщі ${ }^{12}$. Завдяки цій публікації Никифор на десятки літ опинився в центрі уваги митців і глядачів, які захоплювалися його самобутньою творчістю. А справжня слава прийшла до криницького майстра після персональної виставки у Варшаві (1949р.). Відтоді придбати його роботи вважали за честь провідні європейські галереї. Никифор щиро радів як дитина і пишався публікаціями про себе як про відомого художника, про поважну людину, адже саме таким він зображав себе на автопортретах.Митець носив із собою видані публікації йусім показував. На жаль, усе своє життя він провів у бідності та самотності. Хоча на своєму шляху він зустрів небайдужих людей, які підтримали його та допомогли. Серед них особливу допомогу надало художнику подружжя Елла й Анджей Банахи, а також його офіційний опікун живописець Мар'янВлосінський.

Напівглухонімий вуличний художник, який із дитинства зазнав значних поневірянь та приниження, отримав світове визнання. Сьогодні у його рідному містечку Криниці, у центрі міста, куди йому колись забороняли приходити, щоб не псувавкурортно-відпочинкову атмосферу містечка, встановлено пам'ятник та відкрито музей (1995 р.). Цей музей якраз став привабливим місцем для відпочивальників і туристів. Так само великої популярності набув пам'ятник Никифору у Львові, що представляє скульптура "веселого художника", який сидить на камені з пензликом, фарбами та аркушем із піднятою рукою і зведеним пальцем угору, наче він мав бажання щось важливе проголосити. Вже стало традиційним для львів'ян та гостей міста, що для сповнення мрій і бажань необхідно потерти ніс або палець Никифора. I справді, художник-примітивіст бачив світ як палітру яскравих барв, які змінювали сіру

11 В. Лесич, Никифор з Криниці, Мюнхен 1971, с. 31-38.

12 Див.: J. Wolf, Malarze naiwnego realizmu w Polsce. Nikifor, „Arkady” 1938, nr 3, s. 24-30. 
буденність на квітучий сад. Никифор заслужено “перебуває” у центрі міст, у центрі подій, серед людей. Він любив цей прекрасний світ і цінував його, бачив його по-дитячому щиро, неспотворено. I хоча він не вмів добре говорити і мав проблеми порозуміння з іншими, та передав нам своєрідне послання, яке зараз намагаємося зрозуміти через мову символіки його картин.

Чи варто вести суперечку, до якої національності він належить? Чи варто "перетягувати" плоди його світової слави?Адже для художника це питання не відігравало жодної ролі. Він був криничанином, дитиною Бескидів із неповторною природою, де на колишній польській території Австро-Угорщини досить гармонійно співіснували різні народи, плекали власну культуру. Гіркі повороти історії спричинили багато людських трагедій, зокрема переселення корінного населення - лемків та поляків із теперішньої польської та української територій. Але ці та інші політичні незгоди були поза увагою та розумінням художника. Саме тому з-під пензлика майстра поставали позачасові йпозаполітичні, нічим не заангажовані образи земного життя. Від його картин віє приємним вітром найдорожчої домівки, щоденних радощів, захопленням від побаченого, гумором, покорою і щирістю. Це все те, що об'єднує всіх нас, незалежно у якому кутку нашої планети ми з'явилися на світ. Отже, творчість знаменитого художника втілила в себе різноманіття культур, зокрема української, польської та лемківської, яка стала невіддільною частиною обох народів та своєрідною зв'язковою ланкою у спільному історичному минулому.

Вдивляючись у картини із зображенням мальовничого гірського містечка Криниця, думками повертаюсь у ті давні часи. Уявляю маленького Епіфанія (Никифора),якого мати Євдокія веде за руку. Але не просто веде, а тягне, бо поспішає, іде швидко, дитина ледво встигає за нею. Мешканці Криниці допомагали бідній самотній жінці з маленьким хлопчиком, завжди давали щось поїсти, запрошували зайти і погрітися. Жінка майже не розмовляла, щось намагалася сказати своїм високим голосом, але мало що було зрозумілим...Саме так згадувала про Никифора та його матір моя бабуся, Марія Гурей, корінна криничанка, місцева кравчиня, яку в 1947 році з дітьми (чоловік помер) депортували в колишній Радянський Союз на українські землі в місто Монастириська, Тернопільської області. Вона теж приймала у свій дім Євдокію та Никифора, добре їх пам'ятала. На жаль, усе вже залишилося у минулому. Бабуся так і не дізналася про світову славу свого земляка. Але, можливо, десь у далеких світах, як передбачав геніальний примітивіст, вони зустрілися у райському квітучому саду здійснених мрій, одна 3 яких була найзаповітнішою - повернутися до рідної Криниці. 


\section{БІБЛІОГРАФІЯ}

Banach, Andrzej. 2004. Nikifor. Warszawa: Wydawnictwo Akrady.

Bihalji-Merin Oto. 1961. Modern Primitives: Masters of Naive Painting. New York: Harry N. Abrams.

Butenko Ânìna. 2021. Matejko z Krinici. "Den"”. W: https://day.kyiv.ua/uk/article/kultura/ mateyko-z-krynyci [БутенкоЯніна. 2021.Матейко з Криниці. “День”. B: https:// day.kyiv.ua/uk/article/kultura/mateyko-z-krynyci].

Klâštorna Natalâ. 2003. Hotìv lemko malûvati. "Ukraïna moloda". W: http://www.los. org.pl/index.php?glowna=publicystykaszczegoly\&idealny=36 [Кляшторна Наталя. 2003. Хотів лемко малювати. “Україна молода”.B: http://www.los.org.pl/index.php ?glowna=publicystykaszczegoly\&idealny=36].

Kolomiêc' Rostislav. 2020. NikiforDrovnâk. Harkìv: Folìo [Коломієць Ростислав. 2020. Никифор Дровняк.Харків: Фоліо].

Lesič Vadim. 1971. NikiforzKrinicì. Mûnhen: "Sučasnìst"” [Лесич Вадим. 1971. Никифор з Криниці. Мюнхен: "Сучасність”].

Noha Oles. 2005.Nikifor Epifanii Drowniak: Ukrainischer Maler aus dem Lemkenland. Ред. Markowicz M. Düren: Ukraina e.V.

RâbenkoSergìj. 2020. Operaciâ «Vìsla»: genocid, voênnijzločin čietnična čistka. "İstoričnapravda".W: [Рябенко Сергій. 2020. Операція «Вісла»: геноцид, воєнний злочин чи етнічна чистка. “Історична правда”. B: https://www.istpravda.com.ua/ $\operatorname{articles} / 2020 / 07 / 10 / 157801 /]$.

WolfJerzy. 1938. Malarze naiwnego realizmu w Polsce. Nikifor. „Arkady” nr 3: 24-30.

\section{NIKIFOR KRYNICKI CZY EPIFANIUSZ DROWNIAK - FENOMEN OSOBOWOŚCI}

Streszczenie: Artykuł został poświęcony postaci Nikifora Krynickiego, fenomenalnego przedstawiciela malarstwa prymitywnego z polskiego miasteczka Krynica Górska. Jego obrazy cieszyły się szerokim uznaniem nie tylko w kraju, ale i za granicą, choć sam malarz-samouk nie do końca zdawał sobie sprawę ze swej popularności. Był głuchoniemy od urodzenia i niemal niepiśmienny, jednakże swój stosunek do otaczającego świata przekazywał za pomocą niezrównanych obrazów. Autor artykułu snuje rozważania nad życiem i twórczością artysty, stawia tez pytania na temat prawdziwego nazwiska i przynależności narodowej malarza.

Słowa klucze: fenomen, artysta-samouk, malarstwo prymitywne, narodowość

\section{НИКИФОР КРИНИЦЬКИЙ, ЧИ ЕПІФАНІЙ ДРОВНЯК - ФЕНОМЕН ОСОБИСТОСТИ}

Резюме: Статтю присвячено феноменальному художнику, представнику наївного малярства $з$ польського містечка Криниця Никифору Криницькому. Його картини знайшли оцінку та визнання світового рівня, але маляр-самоук до кінця свого життя цього зовсім не усвідомлював. Глухонімий з народження, майже неписьменний, передає своє відношення до навколишнього світу своїми неперевершеними картинами. У статті розглядаються питання його життєвого і творчого шляху, а також частково і питання про справжнє ім'я художника і його національність.

Ключові слова: феномен, маляр-самоук, наївне малярство, національність 
